\title{
Ocena skutków ekonomicznych amerykańsko-chińskiej wojny handlowej w kontekście krajów rozwijających się
}

\author{
Aleksandra Makowska \\ Uniwersytet Gdański \\ Wydział Ekonomiczny, Katedra Ekonomiki i Funkcjonowania Przedsiębiorstw Transportowych \\ E-mail:om@life.pl \\ tutor: dr Sylwia Machowska-Okrój \\ Uniwersytet Gdański \\ Wydziat Ekonomiczny, Katedra Mikroekonomii
}

Stowa kluczowe: wojna handlowa, kraje rozwijające się, Chiny, handel międzynarodowy

\section{Wstęp}

Współcześnie konflikty handlowe rzadko przyjmują tak otwartą formę jak wojna handlowa pomiędzy Stanami Zjednoczonymi a Chińską Republiką Ludową, która rozpoczęła się w styczniu 2018. Wojna handlowa zarówno stanowi kulminację protekcjonistycznych nastrojów, jak i pole do obserwacji reakcji interesariuszy konfliktu.

W kontekście globalnej gospodarki i łańcuchów dostaw, amerykańsko-chiński konflikt handlowy dotknął całego świata, a w szczególności krajów rozwijających się. Jako podmioty o dużym potencjale gospodarczym, z uwagi na swój status i związane z nim korzyści (m.in. przewagi komparatywne), kraje rozwijające się należą do obszaru zainteresowania wielu badaczy.
Niniejszy artykuł ma na celu zbadanie oraz scharakteryzowanie wpływu wojny handlowej na dynamikę i strukturę obrotów handlowych z perspektywy krajów rozwijających się. W pierwszej części artykułu przedstawiono zarys konfliktu oraz amerykańskochińską relację ekonomiczną w kontekście handlu towarowego przed wprowadzeniem wzajemnych sankcji handlowych. Druga część artykułu to prezentacja wyników badań na temat skutków ekonomicznych i podobieństw wśród reakcji krajów rozwijających się (wg. klasyfikacji ONZ), zaangażowanych w handel z Chinami. Do przedstawienia zarysu konfliktu handlowego korzystano z tzw. desk research, metody analizy danych zastanych, oraz programu Excel do przedstawienia zmian handlowych na przestrzeni lat 2000-2020.

Badanie reakcji ekonomicznej zostało przeprowadzone w dwóch etapach. W pierwszej kolejności zastosowano rachunek porównawczy wobec danych handlowych dla lat 2016-2019 oraz zilustrowano 
normalność rozkładu tychże za pomocą histogramów w programie Statistica. Następnie przeprowadzono badanie reakcji ekonomicznych krajów rozwijających się w obrębie obrotów wymiany handlowej z Chinami, w celu wyróżnienia metodą k-średnich grup charakteryzujących się podobieństwami. Wykorzystano 13 kryteriów grupujących oraz metodą Warda wyznaczono docelową liczbę skupień, a następnie zastosowano tę informację do wyłonienia "naturalnych" ugrupowań w metodzie k-średnich. Powstałe skupienia scharakteryzowano na podstawie posiadanych danych handlowych. Na potrzeby badania przyjęto trzy hipotezy badawcze:

H1. Większość krajów rozwijających się, zaangażowanych w wymianę handlową z Chinami, zwiększyło swój eksport do Chin po roku 2018.

H2. Kraje ASEAN w szczególności odniosły korzyści z konfliktu amerykańskochińskiego w postaci poprawy bilansu handlowego i eksportu do Chin.

H3. Występuje korelacja pomiędzy położeniem geograficznym a skutkami ekonomicznymi wojny handlowej.

Tło wojny handlowej z chińskiej perspektywy

Genezy współczesnego konfliktu amerykańsko-chińskiego można upatrywać na początku XXI wieku. Trendy globalizacyjne sprzyjały działaniom Chin, które w 1978 r. po wieloletniej izolacji rozpoczęły proces ekonomicznej integracji ze światową gospodarką (vide "polityka otwartych drzwi” Denga Xiaopinga). W ramach realizowanej „polityki wyjścia” (ang. go-out policy), Chińska Republika Ludowa dołączyła w 2001 r. do Światowej Organizacji Handlu.

Jako kraj rozwijający się Państwo Środka charakteryzowało się licznymi przewagami komparatywnymi obejmującymi niższe koszty produkcji, a także regulacjami prawnymi sprzyjającymi napływowi zagranicznych inwestycji bezpośrednich. W efekcie od blisko 30 lat Chiny odnotowują nadwyżkę bilansu płatniczego (Liu i Woo, 2018), a od ponad dekady są największym eksporterem na świecie (Bank Światowy, 2021). Skuteczne realizowanie przyjętych strategii rozwoju - sformalizowanych m.in. w tzw. planach pięcioletnich - doprowadziło do umocnienia się pozycji Chin na scenie światowej oraz w łańcuchach dostaw, również wobec Stanów Zjednoczonych. W 2020 r. Chiny osiągnęły status największej gospodarki na świecie wg. PKB mierzonego parytetem siły nabywczej (Bank Światowy, 2021).

Narastające nastroje protekcjonistyczne (Puślecki, 2018) osiągnęły kulminację w 2018 r. w postaci "wybuchu" wojny handlowej (ang. trade war) pomiędzy rywalami. W całej złożoności relacji amerykańsko-chińskich wojna handlowa miała trzy główne przesłanki (Liu i Woo, 2018):

1. chroniczny deficyt handlowy USA,

2. kontrowersje związane z kradzieżą własności intelektualnej przez chińskie przedsiębiorstwa i nielegalnymi praktykami w tym zakresie,

3. oraz rzekome starania Państwa Środka w celu osłabienia bezpieczeństwa narodowego oraz pozycji Stanów Zjednoczonych na arenie międzynarodowej.

Narzędzia, jakie zastosowano w trakcie wojny handlowej, obejmują instrumenty taryfowe w postaci ceł dodatkowych i odwetowych, zakaz użytkowania telefonów marki Huawei przez amerykańskich urzędników oraz zakaz sprzedaży amerykańskich komponentów Huawei Technologies Co Ltd. Oba kraje utworzyły także listy "niewiarygodnych podmiotów". Przebieg konfliktu był bardzo burzliwy; od początku 2018 do końca 2020 r. można doliczyć się nawet kilkunastu 


\section{Tutoring Gedanensis}

podwyżek stawek taryfowych, z czego najwyższa wartość stawki to 25\%, nałożona na m.in. import stali, nie tylko z Chin (Majewski, 2019). W związku z licznymi podwyżkami średnia stawka celna w chińskim imporcie wzrosła z 8\% do 21\%, a w amerykańskim z 3\% do 21\% (Ambroziak, 2020). Należy odnotować również fakt, że niektóre nałożone przez Stany Zjednoczone cła nie obejmowały wyłącznie produktów importowanych z Chin, a ogólną kategorię produktową.
Przed nałożeniem dodatkowych ceł, w 2017 i 2018 r. Chiny eksportowały dobra o wartości ponad 500 mld USD, przy czym import wynosił ok. 120 mld USD (National Bureau of Statistics of China, 2021). Dotychczasowy rosnący trend wzrostu eksportu i bilansu handlowego załamał się w 2019 r., co zilustrowano na ryc. 1 i 2.

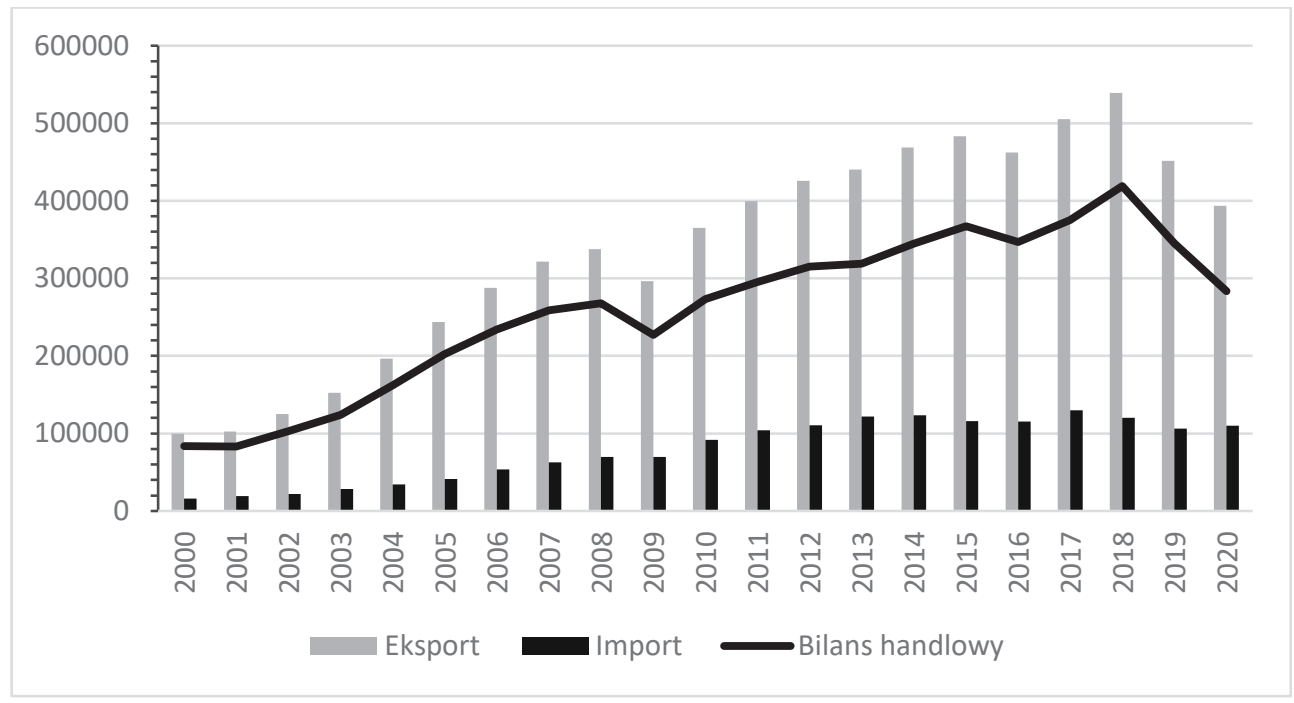

Ryc. 1. Wymiana towarowa Chin ze Stanami Zjednoczonymi w mln USD (2000-2020) (opracowanie własne)

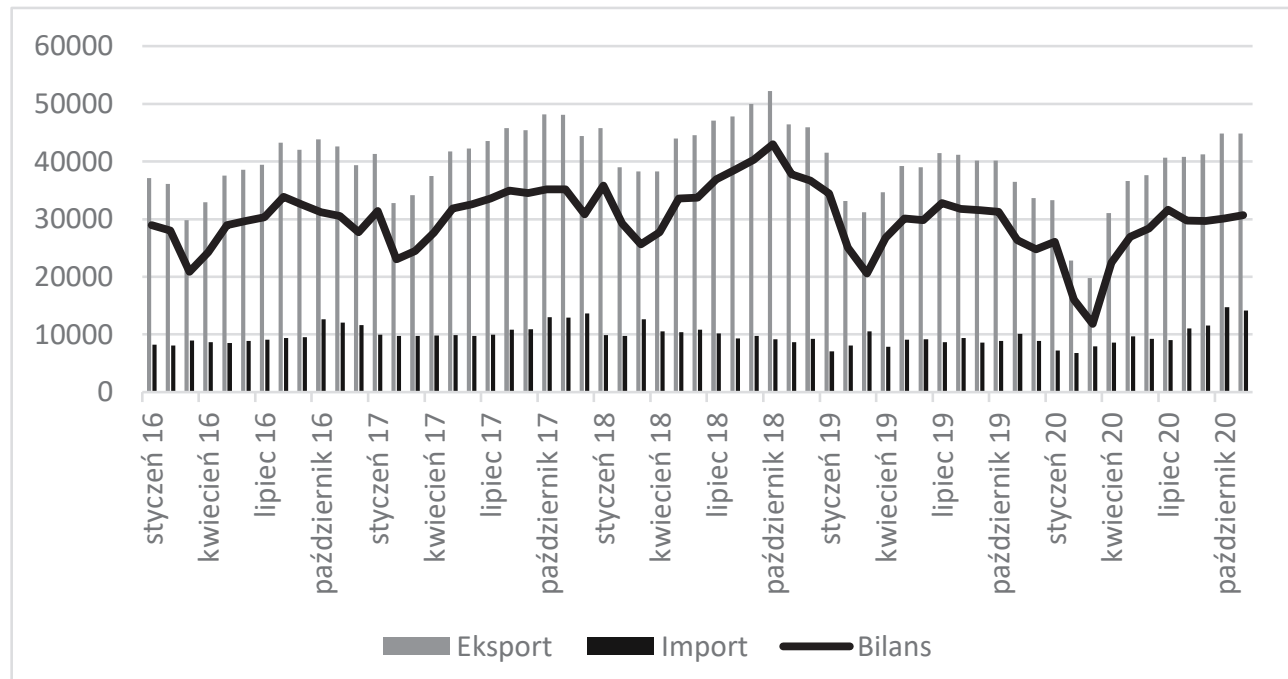

Ryc. 2. Wymiana towarowa Chin ze Stanami Zjednoczonymi w mln USD (styczeń 2016 - październik 2020) (opracowanie własne) 
W 2019 r. wielkość eksportu chińskiego do USA spadła o blisko $17 \%$, do poziomu 452 mld USD, a import wyniósł 106 mld USD . W wyniku działań podjętych przez Stany Zjednoczone, deficyt handlowy zmniejszył się o 73,9 mld USD (17,6\% r/r) (Ambroziak, 2020), z czego spadek wolumenu wymiany towarowej wyniósł $61 \mathrm{mld}$ USD (United States Census Bureau, 2021).

Zmiany w wolumenie obrotów towarowych pomiędzy styczniem 2018 a październikiem 2020 są wyraźnie pogłębione wporównaniu do okresu poprzedzającego (Ryc. 2). Trend spadkowy zainicjowany na przełomie października i listopada 2018 r., w styczniu osiągnął najniższy punkt - w tym samym czasie, gdy nałożone zostały pierwsze cła przez Stany Zjednoczone. W następnych miesiącach miesiącach rozmów oraz negocjacji eksport Chin wzrósł ponownie, powracając do poziomu sprzed omawianego okresu, aby w pierwszym kwartale 2020 roku osiągnąć najniższy poziom od początku wojny handlowej. Jak relacjonuje United States Trade Representative, zmiany wywołane narzędziami taryfowymi nie zmieniły statusu Chin jako największego dostawcy dóbr do Stanów Zjednoczonych.

Konflikty - w tym konflikty handlowe - jako zjawiska gospodarcze mało przewidywalne negatywnie oddziałują na rynek; przyjmuje się, że koszty prowadzenia wojny handlowej są wyższe niż jej korzyści (Nicita, 2019). Wyższe ceny dla konsumentów finalnych, trudniejszy dostęp do oferty, niższe obroty oraz $w$ związku z tym niższe przychody ze sprzedaży dla producentów dóbr oraz potencjalna utrata dotychczasowych kontrahentów to kilka z zidentyfikowanych skutków wojny handlowej (Gadomski, 2018).

Dla świata - w szczególności krajów rozwijających się - wojna handlowa w długim horyzoncie czasowym oznacza szansę na przechwycenie nadwyżki towarowej lub zwiększenie własnego eksportu i poprawienie bilansu płatniczego z którąkolwiek ze stron konfliktu (Gadomski, 2018). Efekt trade diversion, rozproszenia handlu, polega na zróżnicowaniu struktury podmiotowej w imporcie danego państwa pod wpływem bodźca (Nicita, 2019); miejsce chińskich przedsiębiorstw mogą zająć - nie tylko w najbliższej przyszłości - przedsiębiorstwa pochodzące z Tajwanu, Wietnamu czy Meksyku (Gadomski, 2018). Trade war, pomimo podpisania wstępnego porozumienia w styczniu 2020 r. (Donnan i in., 2020), jest konfliktem niezakończonym (McDonald i Wiseman, 2021).

Tło wojny handlowej z chińskiej perspektywy

Po roku wojny handlowej, Chińska Republika Ludowa poprawiła swój bilans handlowy z ponad połową badanych krajów, powiększając nadwyżkę eksportu nad importem w przypadku 75 z 138 państw. W tabeli 1, w myśl zasady Pareto zaprezentowano zestawienie dwudziestu ośmiu największych wzrostów i spadków dynamiki bilansu handlowego ChRL na przełomie 2018 i 2019 roku, w porównaniu do dwóch poprzedzających analogicznych okresów (przełom 2016/2017 i 2017/2018). Całe badanie objęło łącznie 138 państw.

Fluktuacje bilansu handlowego Chin z krajami rozwijającymi się na przestrzeni lat 2016-2019 obejmują zarówno przypadki bardzo gwałtownych zmian wzrostowych (np. Armenia, Liberia, Rwanda czy Wietnam), jak i spadkowych (Azerbejdżan, Macedonia Północna, Argentyna) oraz mieszanych (Trinidad i Tobago, Czad, Korea Południowa). Największy wzrost wartości dynamiki w okresie wojny handlowej odnotowano w przypadku Trinidadu i Tobago, a naj- 


\section{Tutoring Gedanensis}

większe spadki dynamiki wobec Czadu, Azerbejdżanu i Nigerii. W przypadku niektórych państw, dla których wielkość dynamiki osiąga kilkucyfrową zmianę, należy mieć na uwadze względność miary; przykładowo Iran eksportował w 2018 r. do
Chin o 3 mld USD więcej niż w 2017 (odpowiednio: 21,11 mld i 18,55 mld), podczas gdy import irański spadł o ok. 4 mld (13,9 mld USD i 18,58 mld), przez co bilans handlowy z $31 \mathrm{mln}$ zwiększył się do 7,16 mld USD na niekorzyść Chin.

Tab. 1. Dynamika bilansu handlowego Chin z krajami rozwijającymi się w latach 2016-2019 (opracowanie własne na podstawie badań własnych)

\begin{tabular}{|c|c|c|c|c|c|c|c|c|}
\hline \multirow{2}{*}{ L.p. } & \multirow{2}{*}{ Państwo } & \multicolumn{3}{|c|}{$\begin{array}{l}\text { Dynamika bilansu handlo- } \\
\text { wego }\end{array}$} & \multirow{2}{*}{ Państwo } & \multicolumn{3}{|c|}{$\begin{array}{c}\text { Dynamika bilansu handlo } \\
\text { wego }\end{array}$} \\
\hline & & $\begin{array}{l}2016 / \\
2017\end{array}$ & $\begin{array}{l}2017 / \\
2018\end{array}$ & $\begin{array}{c}2018 / \\
2019\end{array}$ & & $\begin{array}{l}2016 / \\
2017\end{array}$ & $\begin{array}{l}2017 / \\
2018\end{array}$ & $\begin{array}{l}2018 / \\
2019\end{array}$ \\
\hline 1 & Trinidad i Tobago & $44 \%$ & $-115 \%$ & $698 \%$ & Czad & $672 \%$ & $-154 \%$ & $-296 \%$ \\
\hline 2 & Armenia & $-6 \%$ & $-44 \%$ & $246 \%$ & Azerbejdżan & $188 \%$ & $-170 \%$ & $-289 \%$ \\
\hline 3 & Burundi & $-9 \%$ & $-34 \%$ & $110 \%$ & Niger & $-95 \%$ & $-4471 \%$ & $-216 \%$ \\
\hline 4 & Urugwaj & $185 \%$ & $-1 \%$ & $107 \%$ & Macedonia Północna & $-120 \%$ & $-764 \%$ & $-121 \%$ \\
\hline 5 & Liberia & $34 \%$ & $-10 \%$ & $103 \%$ & Argentyna & $107 \%$ & $14 \%$ & $-110 \%$ \\
\hline 6 & Rwanda & $32 \%$ & $27 \%$ & $82 \%$ & Ekwador & $39 \%$ & $-6 \%$ & $-101 \%$ \\
\hline 7 & Uzbekistan & $219 \%$ & $27 \%$ & $76 \%$ & Brunei & $-1 \%$ & $370 \%$ & $-85 \%$ \\
\hline 8 & Namibia & $-125 \%$ & $-606 \%$ & $75 \%$ & $\begin{array}{l}\text { Republika Środkowoafrykań- } \\
\text { ska }\end{array}$ & $-6 \%$ & $133 \%$ & $-70 \%$ \\
\hline 9 & Wietnam & $-11 \%$ & $-6 \%$ & $69 \%$ & Tajlandia & $128 \%$ & $-43 \%$ & $-67 \%$ \\
\hline 10 & Jemen & $-36 \%$ & $17 \%$ & $69 \%$ & Kuba & $-36 \%$ & $-38 \%$ & $-50 \%$ \\
\hline 11 & Gabon & $74 \%$ & $40 \%$ & $65 \%$ & Czarnogóra & $-13 \%$ & $106 \%$ & $-48 \%$ \\
\hline 12 & Burkina Faso & $28 \%$ & $-21 \%$ & $58 \%$ & Wenezuela & $80 \%$ & $15 \%$ & $-47 \%$ \\
\hline 13 & Sierra Leone & $-3721 \%$ & $-179 \%$ & $58 \%$ & Iran & $-98 \%$ & $-23109 \%$ & $-46 \%$ \\
\hline 14 & Białoruś & $-36 \%$ & $36 \%$ & $55 \%$ & Mauretania & $-41 \%$ & $141 \%$ & $-44 \%$ \\
\hline 15 & Filipiny & $3 \%$ & $12 \%$ & $43 \%$ & Erytrea & $20 \%$ & $110 \%$ & $-41 \%$ \\
\hline 16 & Kambodża & $22 \%$ & $23 \%$ & $41 \%$ & Bahamy & $-16 \%$ & $81 \%$ & $-41 \%$ \\
\hline 17 & Nepal & $12 \%$ & $11 \%$ & $37 \%$ & $\begin{array}{l}\text { Demokratyczna Republika } \\
\text { Konga }\end{array}$ & $112 \%$ & $67 \%$ & $-39 \%$ \\
\hline 18 & Zimbabwe & $26 \%$ & $4 \%$ & $36 \%$ & Korea Południowa & $15 \%$ & $28 \%$ & $-35 \%$ \\
\hline 19 & Zjednoczone Emiraty Arabskie & $-18 \%$ & $-18 \%$ & $35 \%$ & Ukraina & $56 \%$ & $62 \%$ & $-34 \%$ \\
\hline 20 & Serbia & $24 \%$ & $51 \%$ & $33 \%$ & Laos & $-50 \%$ & $204 \%$ & $-30 \%$ \\
\hline 21 & Vanuatu & $-13 \%$ & $-7 \%$ & $31 \%$ & Libia & $-140 \%$ & $901 \%$ & $-29 \%$ \\
\hline 22 & Bahrajn & $7 \%$ & $27 \%$ & $31 \%$ & Wyspy Salomona & $60 \%$ & $11 \%$ & $-29 \%$ \\
\hline 23 & Singapur & $-42 \%$ & $42 \%$ & $28 \%$ & Zambia & $43 \%$ & $29 \%$ & $-26 \%$ \\
\hline 24 & Indonezja & $-42 \%$ & $46 \%$ & $28 \%$ & Fidżi & $-5 \%$ & $24 \%$ & $-22 \%$ \\
\hline 25 & Sudan & $0 \%$ & $-25 \%$ & $27 \%$ & Malediwy & $-8 \%$ & $34 \%$ & $-20 \%$ \\
\hline 26 & Gujana & $0 \%$ & $19 \%$ & $27 \%$ & Kuwejt & $73 \%$ & $107 \%$ & $-20 \%$ \\
\hline 27 & Gruzja & $22 \%$ & $23 \%$ & $27 \%$ & Gwinea Równikowa & $172 \%$ & $51 \%$ & $-19 \%$ \\
\hline 28 & Jamajka & $-4 \%$ & $8 \%$ & $26 \%$ & $\begin{array}{l}\text { Republika Zielonego Przy- } \\
\text { lądka }\end{array}$ & $42 \%$ & $13 \%$ & $-18 \%$ \\
\hline
\end{tabular}

Według obliczeń własnych, z wyłączeniem tzw. outliers (przypadków odstających) średnia zmiana r/r w 2019 wyniosła -4\% dla całej próby badawczej, a -24\% dla krajów odnoto-wujących spadek dynamiki i $+26 \%$ dla krajów odnotowujących wzrost. Rozkład wartości dynamiki bilansu handlowego zilustrowano na ryc. 3. 


\section{Tutoring Gedanensis}

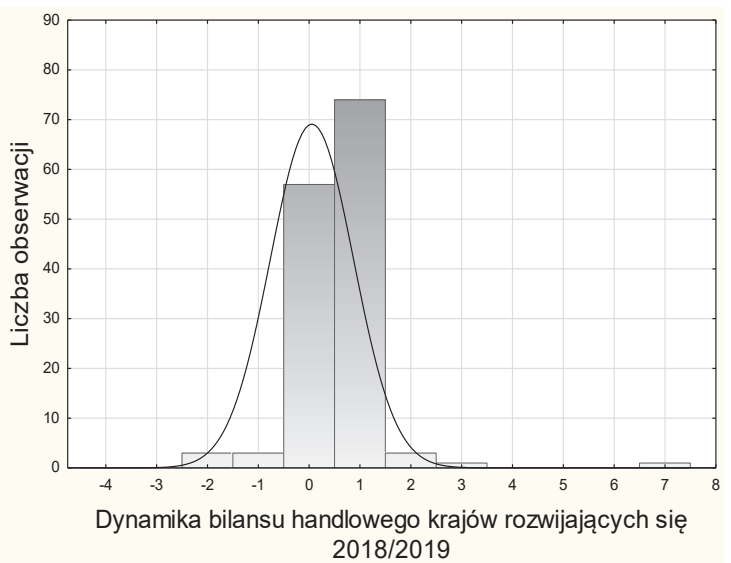

Ryc. 3. Rozkład wartości dynamiki bilansu handlowego w latach 2018-2019 (opracowanie własne)
$\mathrm{Na}$ podstawie histogramu zaobserwowano, że przyjmują one rozkład zbliżony do normalnego, co oznacza stosunkowo równomierne rozłożenie wartości zmiennych, pomimo nieznacznej lewostronnej skośności na przestrzeni lat 2016-2019.

Porównując wartości dynamiki zmian obrotów handlowych zaobserwowano, że 63 państwa wykazały nadwyżkę eksportu nad importem; w przypadku ponad połowy z nich nadwyżka przekroczyła 10\% r/r.

Tab. 2. Dynamika importu chińskich towarów krajów rozwijających się w latach 2016-2019 (opracowanie własne na podstawie badań własnych)

\begin{tabular}{|c|c|c|c|c|c|c|c|c|}
\hline L.p. & Państwo & \multicolumn{3}{|c|}{ Dynamika importu } & Państwo & \multicolumn{3}{|c|}{ Dynamika importu } \\
\hline 1 & Niger & $-3 \%$ & $16 \%$ & $147 \%$ & Brunei & $25 \%$ & $60 \%$ & $-59 \%$ \\
\hline 2 & Liberia & $32 \%$ & $-8 \%$ & $100 \%$ & Namibia & $1 \%$ & $16 \%$ & $-39 \%$ \\
\hline 4 & Libia & $-13 \%$ & $28 \%$ & $72 \%$ & Iran & $13 \%$ & $-33 \%$ & $-31 \%$ \\
\hline 5 & Rwanda & $18 \%$ & $22 \%$ & $60 \%$ & Kuba & $-24 \%$ & $-26 \%$ & $-26 \%$ \\
\hline 6 & Białoruś & $-14 \%$ & $18 \%$ & $58 \%$ & Bahamy & $-23 \%$ & $42 \%$ & $-26 \%$ \\
\hline 7 & Czad & $23 \%$ & $38 \%$ & $51 \%$ & Fidżi & $-5 \%$ & $20 \%$ & $-23 \%$ \\
\hline 8 & Jemen & $-3 \%$ & $12 \%$ & $50 \%$ & Gwinea Równikowa & $12 \%$ & $-15 \%$ & $-22 \%$ \\
\hline 11 & Arabia Saudyjska & $-2 \%$ & $-5 \%$ & $37 \%$ & Zimbabwe & $14 \%$ & $0 \%$ & $-17 \%$ \\
\hline 12 & Turkmenistan & $9 \%$ & $-16 \%$ & $36 \%$ & Wyspy Salomona & $7 \%$ & $22 \%$ & $-17 \%$ \\
\hline 13 & Republika Środkowoafrykańska & $-16 \%$ & $32 \%$ & $35 \%$ & Bhutan & $-87 \%$ & $51 \%$ & $-15 \%$ \\
\hline 14 & Wenezuela & $-31 \%$ & $-52 \%$ & $34 \%$ & Liban & $-4 \%$ & $-2 \%$ & $-15 \%$ \\
\hline 15 & Kambodża & $22 \%$ & $20 \%$ & $33 \%$ & Paragwaj & $33 \%$ & $7 \%$ & $-14 \%$ \\
\hline 16 & Bahrajn & $14 \%$ & $21 \%$ & $31 \%$ & Algieria & $-11 \%$ & $14 \%$ & $-12 \%$ \\
\hline 17 & Gruzja & $22 \%$ & $17 \%$ & $28 \%$ & Malediwy & $-8 \%$ & $25 \%$ & $-12 \%$ \\
\hline 18 & Uzbekistan & $37 \%$ & $30 \%$ & $28 \%$ & Afganistan & $25 \%$ & $19 \%$ & $-10 \%$ \\
\hline 19 & Macedonia Północna & $-13 \%$ & $26 \%$ & $28 \%$ & Haiti & $17 \%$ & $14 \%$ & $-9 \%$ \\
\hline 26 & Jordan & $-5 \%$ & $6 \%$ & $24 \%$ & Urugwaj & $21 \%$ & $-4 \%$ & $-6 \%$ \\
\hline 27 & Gujana & $6 \%$ & $15 \%$ & $23 \%$ & Honduras & $17 \%$ & $14 \%$ & $-5 \%$ \\
\hline 28 & $\begin{array}{l}\text { Wyspy Świętego Tomasza i Ksią- } \\
\text { żęca }\end{array}$ & $8 \%$ & $5 \%$ & $23 \%$ & Pakistan & $6 \%$ & $-8 \%$ & $-5 \%$ \\
\hline
\end{tabular}


Jednakże sama wielkość importu większości krajów poddanych badaniu (85 versus 63) przewyższał wolumen eksportu. Zbadano, że wzrost o więcej niż 10\% w przypadku importu zarejestrowało 51 z 85 państw. W tabeli 2 zawarto zestawienie dwudziestu ośmiu najbardziej skrajnych zmian dynamiki importu chińskich towarów przez kraje rozwijające się w latach 2016-2019.

Reakcje eksportu chińskiego na nałożone cła w 2019 r. charakteryzują się mniejszą rozpiętością wyników, co zaobserwować można w tab. 2. Na ryc. 4 zilustrowano rozkład wartości dynamiki eksportu.

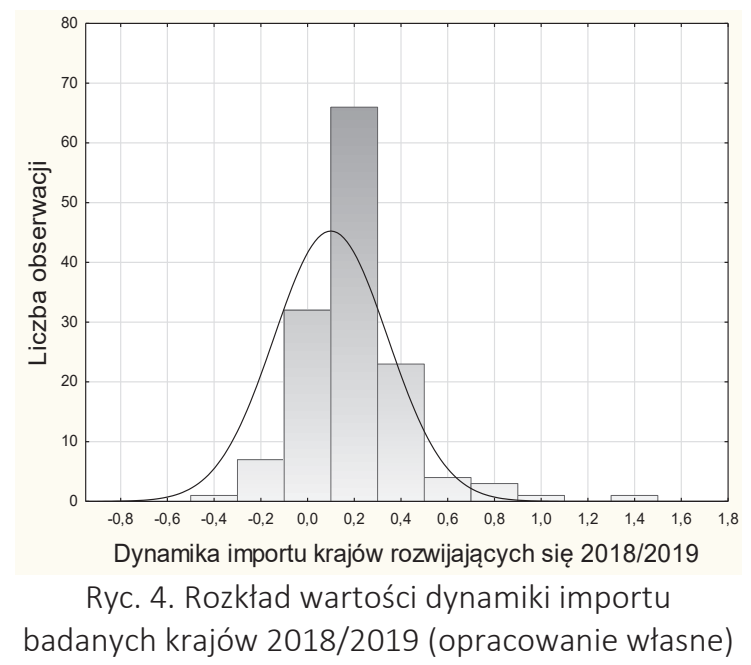

Na podstawie badań własnych i utworzonych histogramów stwierdzono, że w przypadku eksportu również można mówić o rozkładzie zbliżonym do normalnego, czyli symetryczności rozkładu wartości zmiennych. Ryc. 4 charakteryzuje się większą liczebnością przedziałów w strukturze histogramu. Spowodowane jest to brakiem tak skrajnych wartości.

Efekty trade war wobec chińskiego eksportu do krajów rozwijających się cechują się jednolitością; dla krajów odnotowujących nieznaczne wzrosty rok 2019 okazał się być przełomowy dla wzrostu wolumenu kupowanych z Chin dóbr. Porównując wartości z lat ubiegłych z danymi z 2019, nie znalezio- no przesłanek świadczących o wzorcu reakcji w porównaniu do uprzedniego wolumenu poza jednym faktem, jakim jest omówiona "przełomowość" roku 2019. Większość badanych krajów na przełomie 2017 i 2018 wykazała zmianę w kierunku odmiennym do obserwowalnego na przełomie 2016/2017 i 2018/2019.

Z analizy statystycznej przeprowadzonej za pomocą miar syntetycznych wynika, że średnia dynamika eksportu ChRL wyniosła +10\%; porównując wartości dynamiki zaobserwowano, że 78 państw z $\backslash 138$ objętych badaniem posiadało taką samą lub mniejszą dynamikę zakupu dóbr chińskich. W przypadku mediany wynoszącej $+6,3 \%$, wyniki rozkładają się dokładnie po równo: 69 państw importowało z Chin o 6\% więcej lub mniej w porównaniu do roku poprzedzającego.

W 2019 r. aż 11 państw zwiększyło eksport do Chin co najmniej dwukrotnie $r / r$; w kolejności rosnącej są to Macedonia (204\%), Benin (219\%), Gambia (256\%), Czad (371\%), Bhutan (400\%), Panama (453\%), Bahamy (510\%), Timor Leste (716\%), Kiribati (840\%), Malediwy (3174\%) oraz Dżibuti (9920\%).

W 2019 r. 85 z 138 krajów (62\%) sprzedało więcej swoich towarów i usług do Państwa Środka, z czego co drugi z nich odnotował wzrost o co najmniej $10 \%$. Co piąte państwo objęte badaniem wykazało zmianę w różnym kierunku o ponad 50\% na przełomie 2018 i 2019 r.; 30 z 36 z nich to państwa 0 zwiększonym wolumenie sprzedaży $r / r$.

W latach 2016-2019 na podstawie danych dotyczących obrotu towarowego Chin z krajami rozwijającymi się zaobserwować można, że eksport 46 ze wspomnianych 85 krajów o dodatniej dynamice 2018/2019 to eksport charakteryzujący się 


\section{Tutoring Gedanensis}

trendem spadkowym lub o istotnych wahaniach w okresie 2016/2017.

Porównując rozpiętości i stopień zmian eksportu i importu (tab. 2, tab. 3) można stwierdzić, iż to eksport do Chin stał się główną przesłanką zmienności w bilansie handlowym. Średnia dynamika importu ChRL wyniosła dla badanego ogółu $+131 \%$, lecz wyłączając wspomniane przypadki odstające średnia arytmetyczna obniżyła się do zaledwie $8 \%$. W przypadku mediany wynik nie różni się pomiędzy grupą badaną uwzględniającą tzw. outliers (3,9\%) oraz grupą bez nich: (3\%). Rozkład dynamiki eksportu krajów poddanych badaniu przedstawiono na ryc. 5.

Tab. 3. Dynamika eksportu do Chin w latach 2016-2019 (opracowanie własne na podstawie badań własnych)

\begin{tabular}{|c|c|c|c|c|c|c|c|c|}
\hline \multirow{2}{*}{ L.p. } & \multirow{2}{*}{ Państwo } & \multicolumn{3}{|c|}{ Dynamika importu } & \multirow{2}{*}{ Państwo } & \multicolumn{3}{|c|}{ Dynamika importu } \\
\hline & & $\begin{array}{l}2016 / \\
2017\end{array}$ & $\begin{array}{c}2017 / \\
2018\end{array}$ & $\begin{array}{c}2018 / \\
2019\end{array}$ & & $\begin{array}{c}2016 / \\
2017\end{array}$ & $\begin{array}{l}2017 / \\
2018\end{array}$ & $\begin{array}{l}2018 / \\
2019\end{array}$ \\
\hline 1 & Dżibuti & $-85 \%$ & $90 \%$ & $9920 \%$ & Republika Zielonego Przylądka & $-88 \%$ & $97 \%$ & $-90 \%$ \\
\hline 2 & Malediwy & $158 \%$ & $40 \%$ & $3174 \%$ & Wyspy Świętego Tomasza i Książęca & $-100 \%$ & $100 \%$ & $-80 \%$ \\
\hline 3 & Kiribati & $-96 \%$ & $-310 \%$ & $840 \%$ & Palestyna & $-61 \%$ & $73 \%$ & $-68 \%$ \\
\hline 4 & Timor Leste & $441 \%$ & $48 \%$ & $716 \%$ & Jamajka & $206 \%$ & $37 \%$ & $-61 \%$ \\
\hline 5 & Bahamy & $-59 \%$ & $-63 \%$ & $510 \%$ & Paragwaj & $48 \%$ & $18 \%$ & $-59 \%$ \\
\hline 6 & Panama & $65 \%$ & $24 \%$ & $453 \%$ & Nikaragua & $59 \%$ & $73 \%$ & $-57 \%$ \\
\hline 7 & Bhutan & $38 \%$ & $-1700 \%$ & $400 \%$ & Liban & $30 \%$ & $53 \%$ & $-47 \%$ \\
\hline 8 & Czad & $144 \%$ & $-192 \%$ & $372 \%$ & Egipt & $143 \%$ & $27 \%$ & $-46 \%$ \\
\hline 9 & Gambia & $10 \%$ & $-394 \%$ & $256 \%$ & Fidżi & $2 \%$ & $31 \%$ & $-43 \%$ \\
\hline 10 & Benin & $65 \%$ & $-90 \%$ & $219 \%$ & Malawi & $5 \%$ & $0 \%$ & $-43 \%$ \\
\hline 11 & Macedonia Północna & $86 \%$ & $-79 \%$ & $204 \%$ & Belize & $-56 \%$ & $-58 \%$ & $-42 \%$ \\
\hline 12 & Dominikana & $29 \%$ & $7 \%$ & $152 \%$ & Haiti & $19 \%$ & $-1 \%$ & $-40 \%$ \\
\hline 13 & Senegal & $-7 \%$ & $-16 \%$ & $134 \%$ & Burkina Faso & $46 \%$ & $79 \%$ & $-37 \%$ \\
\hline 14 & Gwatemala & $7 \%$ & $-23 \%$ & $129 \%$ & Iran & $25 \%$ & $12 \%$ & $-36 \%$ \\
\hline 15 & Azerbejdżan & $40 \%$ & $-51 \%$ & $128 \%$ & Wenezuela & $30 \%$ & $3 \%$ & $-35 \%$ \\
\hline 16 & Argentyna & $-7 \%$ & $-35 \%$ & $110 \%$ & Honduras & $-14 \%$ & $50 \%$ & $-34 \%$ \\
\hline 17 & Jordan & $32 \%$ & $-30 \%$ & $103 \%$ & Erytrea & $-3 \%$ & $45 \%$ & $-34 \%$ \\
\hline 18 & Ekwador & $20 \%$ & $43 \%$ & $83 \%$ & Republika Środkowoafrykańska & $-11 \%$ & $48 \%$ & $-33 \%$ \\
\hline 19 & Brunei & $59 \%$ & $-42 \%$ & $83 \%$ & Salwador & $154 \%$ & $29 \%$ & $-31 \%$ \\
\hline 20 & Mali & $-31 \%$ & $23 \%$ & $81 \%$ & Wyspy Salomona & $47 \%$ & $12 \%$ & $-27 \%$ \\
\hline 21 & Wybrzeże Kości Słoniowej & $56 \%$ & $37 \%$ & $81 \%$ & Demokratyczna Republika Konga & $58 \%$ & $42 \%$ & $-22 \%$ \\
\hline 22 & Armenia & $8 \%$ & $0 \%$ & $76 \%$ & Zambia & $43 \%$ & $24 \%$ & $-20 \%$ \\
\hline 23 & Trinidad i Tobago & $4 \%$ & $53 \%$ & $74 \%$ & Gwinea Równikowa & $135 \%$ & $31 \%$ & $-19 \%$ \\
\hline 24 & Ukraina & $-6 \%$ & $12 \%$ & $70 \%$ & Pakistan & $-4 \%$ & $16 \%$ & $-17 \%$ \\
\hline 25 & Syria & $-59 \%$ & $-53 \%$ & $62 \%$ & Korea Południowa & $12 \%$ & $13 \%$ & $-15 \%$ \\
\hline 26 & Serbia & $30 \%$ & $5 \%$ & $61 \%$ & Samoa & $-34 \%$ & $-4 \%$ & $-14 \%$ \\
\hline 27 & Białoruś & $18 \%$ & $10 \%$ & $60 \%$ & Kuwejt & $40 \%$ & $42 \%$ & $-12 \%$ \\
\hline 28 & Gabon & $59 \%$ & $23 \%$ & $56 \%$ & Rwanda & $-13 \%$ & $27 \%$ & $-11 \%$ \\
\hline
\end{tabular}

Struktura dynamiki w przypadku eksportu krajów rozwijających się przedstawia się odmiennie od struktury importu z powodu przypadków odstających. Mimo to na podstawie danych urzędów statystycznych Chin i USA można stwierdzić, iż rozkład zmienności jest zbliżony do normalnego. 


\section{Tutoring Gedanensis}

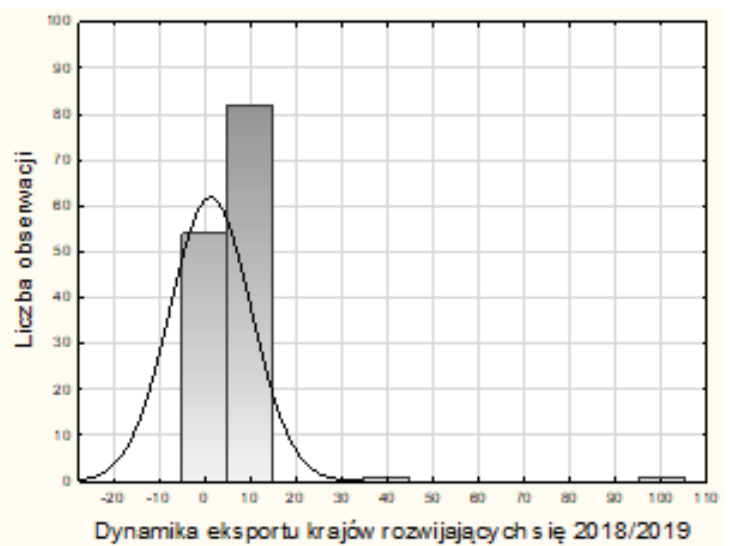

Ryc. 5. Rozkład wartości dynamiki eksportu badanych krajów 2018/2019 (opracowanie własne)

Badaniu struktury i potencjalnych grup o jednakowej reakcji ekonomicznej na amerykańsko-chiński konflikt handlowy poddano 123 państwa o statusie kraju rozwijającego się według klasyfikacji ONZ. Jako metodę badania zastosowano metodę grupowania k-średnich do wyłonienia grup (skupień) o charakterystycznych reakcjach rynkowych oraz metodę Warda do ustalenia docelowej liczby skupień, wymaganej przez pierwszy algorytm.

Zastosowano 13 kryteriów grupujących: wielkość i dynamikę obrotów handlowych (eksportu, importu, bilansu handlowego; dane za rok 2018 i 2019), wielkość i dynamikę PKB w cenach stałych z 2010 r. dla 2018 i 2019, a także zmienną zero-jedynkową odpowiadającą przynależności do ASEAN, gdzie 1 oznaczało przynależność. Wobec braku danych dotyczących wartości PKB w cenach stałych z 2010 roku przypadki były automatycznie usuwane z analizy, w związku z czym liczba badanych krajów to 123 , a nie 138. Wyniki grupowania oraz charakterystykę skupień zaprezentowano w tab. 4.

Tab. 4. Wyniki grupowania metodą k-średnich oraz charakterystyka skupień (opracowanie własne na podstawie badań własnych)

\begin{tabular}{|c|c|c|}
\hline L.p. & Państwa w grupie & Charakterystyka \\
\hline 1 & Brazylia, Indie, Korea Południowa, Rosja & $\begin{array}{l}\text { Kraje BRICS + N-11 (Korea Południowa); niewielkie zmiany war- } \\
\text { tości dynamiki (Korea jako jedyna posiada wartości bezwzględne } \\
\text { powyżej } 7 \% \text {; spadek eksportu do Chin o } 15 \% \text {, dynamiki bilansu } \\
\text { handlowego o } 5 \% \text { ). Wzrost PKB od } 1 \text { do } 5 \% \text {. }\end{array}$ \\
\hline 2 & $\begin{array}{l}\text { Afganistan, Algieria, Angola, Bahamy, Bangla- } \\
\text { desz, Chile, Czarnogóra, Ekwador, Fidżi, Haiti, } \\
\text { Honduras, Izrael, Katar, Kolumbia, Kongo, Ko- } \\
\text { staryka, Kuwejt, Oman, Pakistan, Paragwaj, } \\
\text { Peru, Sri Lanka, Tunezja, Ukraina, Wyspy Sa- } \\
\text { lomona, Zambia, Związek Komorów }\end{array}$ & $\begin{array}{l}\text { Grupa reprezentuje każdy kontynent; skupienie z mniejszością } \\
\text { państw Afryki, głównie Azja i Ameryka. Niski wzrost gospodarczy } \\
\text { odnotowało } 78 \% \text { państw; ok. 1-4\% PKB r/r. Poza Omanem i Chile } \\
\text { ujemna dynamika bilansu handlowego (średnio -17\%). Spadek } \\
\text { chińskiego eksportu, przewaga wartości i częstości wzrostu dy- } \\
\text { namiki eksportu krajów skupienia. }\end{array}$ \\
\hline 3 & $\begin{array}{l}\text { Albania, Armenia, Belize, Boliwia, Bośnia } \\
\text { i Hercegowina, Botswana, Gabon, Jamajka, } \\
\text { Jordan, Kiribati, Lesotho, Maroko, Mołdawia, } \\
\text { Mozambik, Panama, Salwador, Sudan, Suri- } \\
\text { nam, Timor Leste, Urugwaj, Vanuatu, Wyspy } \\
\text { Świętego Tomasza i Książęca }\end{array}$ & $\begin{array}{l}\text { Równomierna reprezentacja regionów ONZ (z nielicznymi wyjąt- } \\
\text { kami, } 2-3 \text { państwa na każdy). Raczej umiarkowany wzrost PKB } \\
\text { (do }+3 \% \text { r/r, niewielki spadek tylko Sudan i Surinam). } \\
\text { Kraje przejmujące zbyt rynkowy; poza Gabonem i Urugwajem, } \\
\text { wzrost importu z Chin. Dwa rodzaje reakcji eksportowych we- } \\
\text { wnątrz grupy: spadki eksportu do Chin, skokowe różnice, lub } \\
\text { znaczne wzrosty eksportu (nawet kilkukrotne w ujęciu r/r). }\end{array}$ \\
\hline 4 & $\begin{array}{l}\text { Argentyna, Benin, Demokratyczna Republika } \\
\text { Konga, Dominikana, Egipt, Etiopia, Ghana, } \\
\text { Gwatemala, Gwinea Bissau, Kamerun, Kenia, } \\
\text { Macedonia Północna, Madagaskar, Maureta- } \\
\text { nia, Mauritius, Mongolia, Papua Nowa Gwi- } \\
\text { nea, Republika Zielonego Przylądka, Senegal, }\end{array}$ & $\begin{array}{l}\text { Głównie kraje afrykańskie (wschód i zachód kontynentu); wzrost } \\
\text { gospodarczy rzędu nawet } 8 \% \text {; najniższy wyniósł } 4 \% \text {. } \\
\text { Co trzeci kraj skupienia wykazał wysokie wartości wzrostu dyna- } \\
\text { miki eksportu. Jednocześnie zaobserwowane wzrosty importu } \\
\text { r/r z Chin były w zdecydowanej większości przypadków znacznie } \\
\text { mniejsze niż w przypadku eksportu. }\end{array}$ \\
\hline
\end{tabular}




\section{Tutoring Gedanensis}

\begin{tabular}{|c|c|c|}
\hline & $\begin{array}{l}\text { Tadżykistan, Tanzania, Togo, Uganda, Wy- } \\
\text { brzeże Kości Słoniowej }\end{array}$ & \\
\hline 5 & $\begin{array}{l}\text { Arabia Saudyjska, Meksyk, Nigeria, Republika } \\
\text { Południowej Afryki, Turcja, Zjednoczone Emi- } \\
\text { raty Arabskie }\end{array}$ & $\begin{array}{l}\text { Niski lub ujemny wzrost PKB r/r. Kraje o cennych zasobach natu- } \\
\text { ralnych lub N-11. Reakcja na wojnę handlową wydaje się korelo- } \\
\text { wać z tym podziałem: Arabia Saudyjska, Nigeria, ZEA odnotowały } \\
\text { silniejsze reakcje. }\end{array}$ \\
\hline 6 & Azerbejdżan, Czad, Macedonia Północna & $\begin{array}{l}\text { Outliers w zakresie dynamiki eksportu do Chin (powyżej 100\%) } \\
\text { i bilansu handlowego (por. tab. 1). }\end{array}$ \\
\hline 7 & $\begin{array}{l}\text { Bahrajn, Burkina Faso, Gambia, Gruzja, Gu- } \\
\text { jana, Gwinea, Irak, Malawi, Nepal, Republika } \\
\text { Środkowoafrykańska, Rwanda, Serbia, Sierra } \\
\text { Leone, Uzbekistan }\end{array}$ & $\begin{array}{l}\text { Wzrost gospodarczy rzędu od +4\% do +9\% r/r. Znaczny i stabilny } \\
\text { wzrost chińskiego eksportu r/r w całym skupieniu. Nieliczne, ale } \\
\text { znaczne spadki eksportu do Chin (Burkina Faso, Malawi, Repu- } \\
\text { blika Środkowoafrykańska, Rwanda, Uzbekistan). Średnia zmiana } \\
\text { bilansu handlowego o } 26 \text { p. p. na korzyść Chin. }\end{array}$ \\
\hline 8 & $\begin{array}{l}\text { Indonezja, Malezja, Singapur, Tajlandia, Wiet- } \\
\text { nam }\end{array}$ & $\begin{array}{l}\text { Kraje ASEAN ( } 5 \text { z 10). Mediana wzrostu gospodarczego wyniosła } \\
4 \% \text {. Wyłącznie Tajlandia odnotowała spadek dynamiki bilansu } \\
\text { handlowego o } 67 \% \text { r/r, a Indonezja importu o 0,1\%. Przeważnie } \\
\text { wzrost importu z Chin, wyższy niż eksportu. }\end{array}$ \\
\hline 9 & Brunei, Filipiny, Kambodża, Laos, Mjanma & $\begin{array}{l}\text { Kraje ASEAN ( } 5 \text { z 10). Mediana wzrostu gospodarczego +5\% r/r. } \\
\text { Podobna sytuacja co w skupieniu nr } 8 . \text {. } \text { wyjątkiem Brunei (-59\%; } \\
\text { skokowe zmiany r/r wszystkich zmiennych poza PKB) znaczne, } \\
\text { przekraczające } 16 \% \text { wzrosty importu z Chin. Brunei i Mjanma } \\
\text { więcej eksportowały do Chin niż importowały. }\end{array}$ \\
\hline 10 & Białoruś, Burundi, Liberia, Libia & $\begin{array}{l}\text { Duży wzrost importu z Chin } r / r \text {, średnio } 73 \% \text {. Z wyjątkiem Libii } \\
\text { każdy z krajów odnotował wzrost bilansu handlowego o średnio } \\
64,2 \%,+/-21 \text { p. p., oraz nadwyżkę importu nad eksportem (tu- } \\
\text { taj: z wyjątkiem Białorusi, różnica } 2 \text { p. p.) }\end{array}$ \\
\hline 11 & $\begin{array}{l}\text { Gwinea Równikowa, Liban, Namibia, Nikara- } \\
\text { gua, Zimbabwe }\end{array}$ & $\begin{array}{l}\text { Spadek PKB r/r, mediana }-6 \% \text {. Spadek importu z Chin (poza Nika- } \\
\text { raguą) o co najmniej } 15 \% \text { r/r. Spadek również eksportu do Chin } \\
\text { (poza Namibią i Zimbabwe, }+2 \% \text { i }+9 \% \text { r } / r \text { ). Bilans handlowy } \\
\text { wzrósł dla tylko tych trzech państw (odpowiednio: }+24 \%,+75 \% \text {, } \\
+36 \% \text { ). }\end{array}$ \\
\hline $12^{*}$ & Hong Kong, Malediwy, Trinidad I Tobago & $\begin{array}{l}\text { Brak jednorodnej reakcji. Skupienie sztucznie złożone z krajów } \\
\text { tworzących "samodzielne" skupienia, outliers, Hong Kong wiel- } \\
\text { kości importu, Malediwy eksportu (tab. 3), Trinidad i Tobago bi- } \\
\text { lansu handlowego (tab. 1). }\end{array}$ \\
\hline
\end{tabular}

Budowa wewnętrzna skupień wynika z podobieństwa poszczególnych elementów składowych względem siebie, i poza nielicznymi opisanymi wyjątkami wewnątrz grup można mówić o podobnej reakcji handlowej państw wewnątrz tych grup na trade war USA-Chiny (tab. 4). Wyłonione skupienia to 11 organicznych zgrupowań o zróżnicowanej liczebności.

Badając właściwości grupowania wobec przyjętych zmiennych ekonomiicznych i kryterium przynależności ASEANu zaobserwowano kilka rodzajów skupień. Wyróżniono grupy państw podobnych gospodarczo (nr 1 i 5), przypadki odstające (nr 6, 12) oraz skupienia krajów o podobnych reakcjach na wojnę handlową ( $\mathrm{nr} 2,3,4,7,10,11) \mathrm{z}$ nielicznymi wyjątkami od trendów w poszczególnych skupieniach, a także kraje ASEAN rozdzielone na skupienia nr 8 i 9.

Skupienie $\mathrm{nr} 1$ to państwa BRICS z wyjątkiem Korei Południowej, która przynależy do tzw. Next Eleven ( $N$-11). Republika Południowej Afryki, która jako ostatnia dołączyła do BRICS, przynależy zaś do skupienia nr 5, aglomeracji krajów bogatych w zasoby naturalne lub N-11. 
Metoda k-skupień jako metoda o charakterze niehierarchicznym daje wyniki w postaci skupień o elementach maksymalnie do siebie podobnych wewnętrznie i maksymalnie różnych od składu innych skupień. Ponadto, jako metoda aglomeracyjna jest wrażliwa na przypadki odstające, które w tab. 4 tworzą samodzielne skupienia. Skupienie $\mathrm{nr} 12$ to skupienie utworzone sztucznie przez autorkę, podczas interpretacji wyników właśnie z przypadków osiągających skrajne wartości. Na podobnej zasadzie utworzono skupienie $\mathrm{nr} 6$, choć miało to miejsce w samym programie Statistica, bez ingerencji autorki badań. Wartym odnotowania jest fakt metodologiczny, że skupienia niedotyczące przypadków odstających liczą minimum 4 państwa składowe, najczęściej 4-5 lub kilkanaście czy dwadzieścia kilka.

Skupienia $\mathrm{nr} 2,3,4,7,10$ oraz 11 różnią się między sobą liczebnością w sposób, który należałoby interpretować jako istnienie lub brak trendu w poszczególnych grupach. Wynika to z łatwości zagregowania krajów w grupy wg. zmiennych standaryzowanych. Minimalizacja odległości pomiędzy obiektami wewnątrz danego ugrupowania (przy jednoczesnej maksymalizacji odległości wobec innych skupień) stanowi parametr wykorzystanego algorytmu k-średnich.

Zaobserwowano zbieżność geograficznego umiejscowienia w stosunku do reakcji na wojnę handlową pomimo nieuwzględnienia zmiennej geograficznej w omawianej analizie. Nie jest ona jednak na tyle wyraźna, aby wysnuwać dalsze wnioski w przyjętym zakresie wynikającego z innej przesłanki niż logiczny związek lokalizacji z miejscem w łańcuchu dostaw. Wyjątkiem są kraje ASEAN (skupienie nr 8 i 9), których skupienie było przewidywane w kontekście przyjęcia zmiennej zero-jedynkowej odpowiadającej przynależności do ugrupowania. W tab. 5 przedstawiono konkretne wartości dynamiki państw członkowskich ASEAN.
Pod względem bilansu handlowego tylko Brunei, Laos i Tajlandia odnotowały dodatni przyrost wartości r/r. Tylko w przypadku Malezji, Mjanma i Brunei dane urzędu statystycznego ChRL wykazały wartość zdecydowanie wzrostową, powyżej $+10 \%$ w wyniku wojny handlowej. Jednocześnie kraje te przechwyciły część towarów z Chin; z wyjątkiem Tajlandii, Indonezji i Brunei importowano co najmniej 12\% więcej niż w 2018 r., po nałożeniu taryf przez Stany Zjednoczone. Stopa wzrostu PKB krajów ASEAN w większości przekroczyła wartość prognozy dla świata, tj. 2,4\%, poza Singapurem.

Tab. 5. Skutki ekonomiczne wojny handlowej na kraje ASEAN - obrót towarowy 2018/2019 (opracowanie własne na podstawie badań własnych)

\begin{tabular}{|l|c|c|c|c|}
\hline Państwo & $\begin{array}{c}\text { Im- } \\
\text { port }\end{array}$ & $\begin{array}{c}\text { Eks- } \\
\text { port }\end{array}$ & $\begin{array}{c}\text { Bilans han- } \\
\text { dlowy }\end{array}$ & PKB \\
\hline Brunei & $-59 \%$ & $83 \%$ & $85 \%$ & $3,9 \%$ \\
\hline Filipiny & $16 \%$ & $-2 \%$ & $-43 \%$ & $6,0 \%$ \\
\hline Indonezja & $6 \%$ & $-0,1 \%$ & $-28 \%$ & $5,0 \%$ \\
\hline Kambodża & $33 \%$ & $5 \%$ & $-41 \%$ & $7,1 \%$ \\
\hline Laos & $21 \%$ & $7 \%$ & $30 \%$ & $4,7 \%$ \\
\hline Malezja & $15 \%$ & $14 \%$ & $-11 \%$ & $4,3 \%$ \\
\hline Mjanma & $17 \%$ & $36 \%$ & $-1 \%$ & $2,9 \%$ \\
\hline Singapur & $12 \%$ & $4 \%$ & $-28 \%$ & $0,7 \%$ \\
\hline Tajlandia & $6 \%$ & $3 \%$ & $67 \%$ & $2,4 \%$ \\
\hline Wietnam & $17 \%$ & $0 \%$ & $-69 \%$ & $7,0 \%$ \\
\hline
\end{tabular}

Z perspektywy Chin wpływ wojny handlowej na strukturę rynków zbytu dla swojego eksportu oraz źródeł importowanych dóbr był bardzo szeroki i istotny, co zostało zilustrowane na rycinach 6 i 7 .

Zastosowana miara, z wyjątkiem tzw. outliers (przekraczających dwukrotność wartości $r / r$ ), eksponuje skalę ekonomicznych skutków konfliktu Stanów Zjednoczonych i Chin na kraje rozwijające się. Można zaobserwować pewną geograficzną zbieżność reakcji negatywnych, zmniejszających 


\section{Tutoring Gedanensis}

saldo bilansu handlowego ChRL - kraje Środkowej Afryki, Azja Południowozachodnia oraz kraje Ameryki Południowej na brzegu zachodnim oraz na południu kontynentu (Ryc. 4). Reakcje zwiększające saldo zaobserwowano wśród krajów z dostępem do linii brzegowej (Ryc. 5).

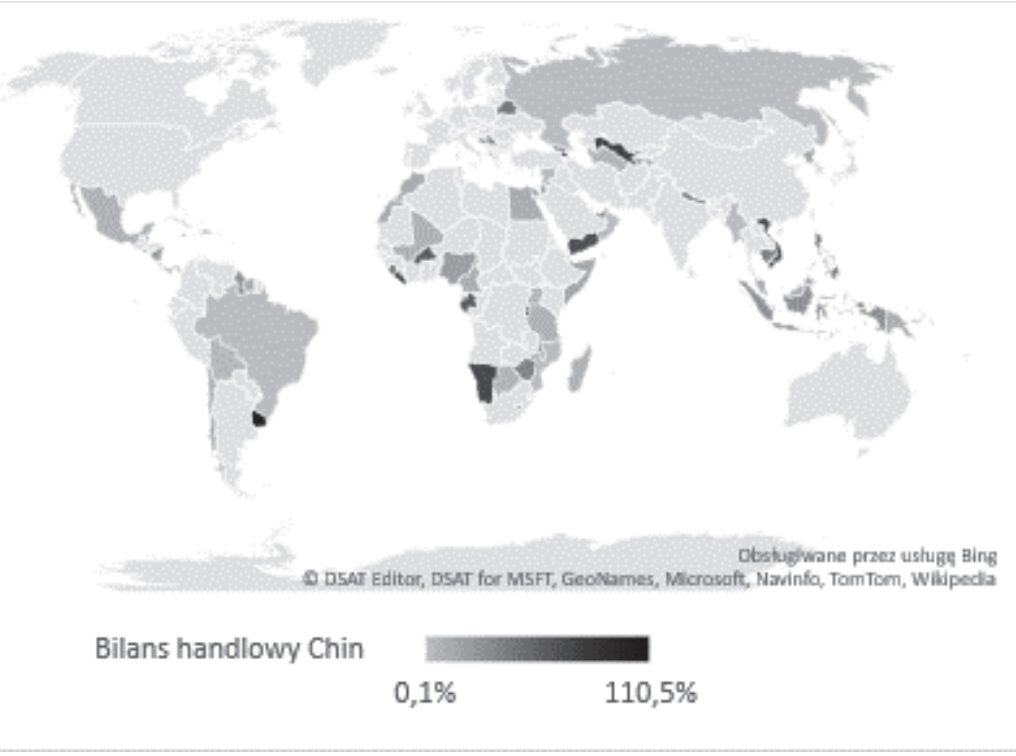

Ryc. 6. Ekonomiczna reakcja krajów rozwijających się na wojnę handlową (dodatnia dynamika bilansu handlowego, z wyłączeniem przypadków odstających) (opracowanie własne)

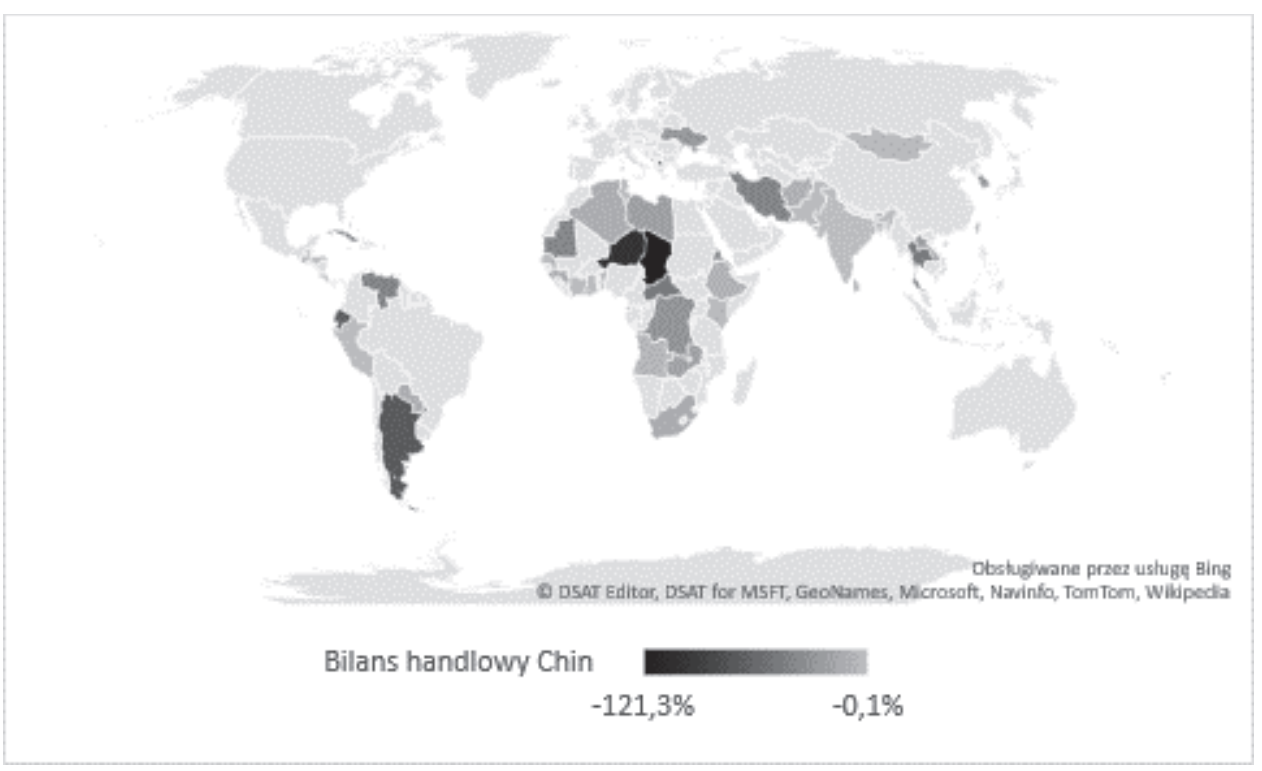

Ryc. 7. Ekonomiczna reakcja krajów rozwijających się na wojnę handlową (ujemna dynamika bilansu handlowego, z wyłączeniem przypadków odstających) (opracowanie własne) 
Podsumowanie i wnioski

Amerykańsko-chińska wojna handlowa rozpo-częta w styczniu 2018 r. nie jest bynajmniej konfliktem zakończonym, pomimo podpisania porozumienia na początku 2020 r. Skutki ekonomiczne zastosowania narzędzi taryfowych są widoczne zarówno w wymianie handlowej obydwóch stron konfliktu, ale również w łańcuchach dostaw, których są istotną częścią. Kraje rozwijające się w sposób szczególny powiązane z gospodarką światową jako podmioty o przewagach komparatywnych doświadczyły tzw. efektu trade diversion, rozproszenia handlu, przejmując część podaży lub popytu Chin, które straciły 20\% wolumenu eksportu sprzed wojny handlowej. Z wyjątkiem Trinidadu i Tobago, rozpiętość zmian w bilansie handlowym objęła trzykrotność spadku (Armenia) i wzrostu wartości bilansu handlowego (Czad, Azerbejdżan, Niger) z perspektywy Chin. Efekt trade diversion pod wpływem wojny handlowej jest jednolity wobec importu z Chin, o czym świadczy normalność rozkładu próby, a także skład i reakcje utworzonych skupień. Na podstawie analizy statystycznej i porównawczej stwierdzić można silniejszą reakcję eksportu niż importu, obserwowalną na zaprezentowanych ilustracjach - lokalizacja geograficzna krajów to głównie Afryka Środkowa i Azja Południowo-Zachodnia. Przypadki odstające takie jak Dżibuti czy Trinidad i Tobago wymagają jednak pogłębionego badania, szczególnie w zakresie kategorii produktowych eksportowanych do Chin, aby zbadać kierunek i charakter przesunięcia źródeł dostaw dóbr. Z dziesięciu krajów ASEAN, tylko Brunei zmniejszyła import z Chin, przy jednoczesnym zwiększeniu eksportu, a bilans handlowy w wyniku wojny handlowej poprawiły dodatkowo Malezja i Mjanma. Podsumowując, pozytywnie zweryfikowano H1; chiński import z krajów rozwijających się stał się główną siłą napędową dla zmian w bilansie handlowym, cechując się bardziej skokowymi zmianami dynamiki. H2 została zweryfikowana negatywnie; większość krajów ASEAN odnotowało raczej wzrosty importu oraz pogorszenie bilansu handlowego. Pozytywnie zweryfikowano H3 zaobserwowano korelację pomiędzy umiejscowieniem geograficznym z reakcją kraju: większość państw pogrupowanych w analizie k-skupień wykazało taką korelację. Ponadto zaobserwowano na podstawie ryc. 6 i 7, że kraje rozwijające się z dostępem do linii brzegowej częściej poprawiały swój bilans handlowy, zaś kraje środkowej Afryki, południowo-zachodniej Azji i zachodniopołudniowych regionach Ameryki Południowej - pogarszały.

\section{Literatura:}

Ambroziak Ł., 2020. Skutki amerykańsko-chińskiej wojny handlowej dla między-narodowych tańcuchów dostaw, Warszawa, Polski Instytut Ekonomiczny, https://pie.net.pl/wp-content/uploads/2018/07/PIE-Raport_Wojna_handlowa.pdf [Dostęp: 16.01.2021].

Bank Światowy, World Bank Open Data [online], https://data.worldbank.org/ [Dostęp: 21.02.2021].

Donnan S., Wingrove J., Mohsin S., 2020. U.S. and China Sign Phase One of Trade Deal [online],15.01.2020,

https://www.bloomberg.com/news/articles/2020-01-15/u-s-china-signphase-one-of-trade-deal-trump-callsremarkable [Dostęp: 30.01.2021].

Gadomski W., 2018. Wojna handlowa - ryzyko dla wzrostu światowego [online], https://www.obserwatorfinan- 
sowy.pl/tematyka/makroekonomia/trendy-gospodarcze/wojna-handlowa-ryzyko-dla-wzrostu-swiatowego/ [Dostęp: 30.01.2021].

Kuepper J., 2019. Next 11 Economies Poised for Growth [online], https://www.thebalance.com/what-are-the-nexteleven-1978980 [Dostęp: 30.01.2021].

Liu T., Woo, W. T., 2018. Understanding the U.S.China Trade War, China Economic Journal, 11:3, 319-340, DOl: 10.1080/17538963.2018.1516256.

http://faculty.econ.ucdavis.edu/faculty/woo/Woo-Articles\%20from\%202012/2018.LiuWoo.Understanding\%20the\%20U\%20S\%20China\%20Tr ade\%20War.pdf [Dostęp: 16.01.2021].

Majewski M., 2019. Konsekwencje i przebieg wojny handlowej pomiędzy Chinami a Stanami Zjednoczonymi, Ekonomia XXI Wieku, 2 (22), 28-41, [online] http://cejsh.icm.edu.pl/cejsh/element/bwmeta1.element.desklighta8ec5eb4-d706-44b0-b8b0aa6a30a89025 [Dostęp: 16.01.2021].

McDonald J., Wiseman P., 2021. Under Biden, China faces renewed trade pressure [online], https://apnews.com/article/joe-biden-donald-trump-technology-beijing-global-trade22f525e41676d4e6abf96f3ca9255d15, [Dostęp: 30.01.2021].

National Buraeu of Statistics of China, Statistical Database [online], http://www.stats.gov.cn/english/ [Dostęp: 27.01.2021].

Nicita A., 2019. Trade and trade diversion effects of Unites States tariffs on China, UNCTAD Research Paper, nr 37 [online], https://unctad.org/system/files/official-document/ser-rp-2019d9_en.pdf [Dostęp: 16.01.2021].

Office of the United States Trade Representative, The People's Republic of China [online], https://ustr.gov/ [Dostęp: 21.02.2021].
Organizacja Narodów Zjednoczonych, 2020. World Economic Situation and Prospects [online], https://www.un.org/development/desa/dpad/wp-content/uploads/sites/45/WESP2020_Annex.pdf [Dostęp: 30.01.2021).

Puślecki Z. W., 2018. Protekcjonizm regulacyjny we współczesnym handlu między-narodowym, Środkowoeuropejskie Studia Polityczne, Nr 2/2018, 65-79. DOI: 10.14746/ssp.2018.2.5 [online] http://ssp.amu.edu.pl/wp-content/uploads/2018/07/ssp-2018-205.pdf [Dostęp: 16.01.2021).

Strona rządu Republiki Południowej Afryki, Fifth BRICS Summit - general background, https://www.gov.za/events/fifth-bricssummit-general-background\# [Dostęp: 30.01.2021].

Timmons, H., 2020. Timeline: Key dates in the U.S.-China trade war [online], https://www.reuters.com/article/ususa-trade-china-timeline/timeline-keydates-in-the-u-s-china-trade-waridUSKBN1ZE1AA [Dostęp: 16.01.2021].

United States Census Bureau, U.S. International Trade Data [online], https://www.census.gov/ [Dostęp: 12.02.2021].

Notka o autorce: Studentka II roku studiów magisterskich na kierunku ekonomia, specjalność diagnozowanie ekonomiczne i funkcjonowanie przedsiębiorstw Wydziału Ekonomicznego UG. Zafascynowana mechanizmami i relacjami funkcjonowania rzeczywistości zarówno gospodarczej, jak i metafizycznej, aspirująca poliglotka. W szerokim spektrum zainteresowań koncentruje się obecnie na metodologii badań ekonomicznych, eksploracji filozofii nauki i rozwijaniu pasji pisarsko-artystycznych. 